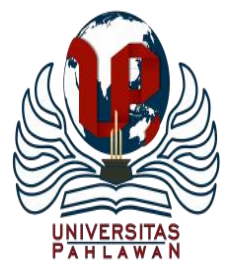

Edukatif : Jurnal Ilmu Pendidikan Volume 3 Nomor 5 Tahun 2021 Halm 2470 - 2477

EDUKATIF: JURNAL ILMU PENDIDIKAN

Research \& Learning in Education

https://edukatif.org/index.php/edukatif/index

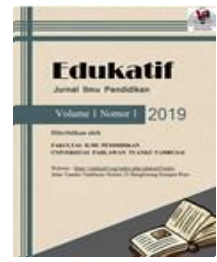

\title{
Pengaruh Pembelajaran Daring di Masa Pandemi Covid-19 bagi Psikologis Siswa Sekolah Dasar
}

\author{
Fatimah Nur Rahma ${ }^{1 凶}$, Fransisca Wulandari ${ }^{2}$, Difa UI Husna ${ }^{3}$ \\ Universitas Ahmad Dahlan Yogyakarta, Indonesia ${ }^{1,2,3}$ \\ E-mail : fatimah1900031012@webmail.uad.ac.id ${ }^{1}$, fransisca1900031034@webmail.uad.ac.id², \\ difaul.husna@pai.uad.ac.id ${ }^{3}$
}

\begin{abstract}
Abstrak
Adanya pembatasan kegiatan di sekolah mengikuti kebijakan dari pemerintah akibat pandemi covid-19 yang semula seluruh kegiatan belajar mengajar di adakan dengan bertatap muka sekarang beralih menjadi pembelajaran jarak jauh dengan menerapkan model pembelajaran dalam jaringan (daring). Tujuan dari penelitian ini adalah untuk memperoleh gambaran dan menelaah model pembelajaran daring di masa covid-19 terhadap psikologis siswa sekolah dasar. Metode yang digunakan memakai pendekatan kualitatif dengan bentuk studi kepustakaan. Analisis data yang digunakan menggunakan analisis isi, yaitu mengumpulkan, mencatat, mengolah data dan menarik kesimpulan hingga menjadi data yang ilmiah. Hasil pencapaian penelitian menunjukkan jika model pembelajaran daring yang telah berjalan selama satu tahun ini tidak berjalan efektif bagi siswa sekolah dasar. Hasil penyampaian pembelajaran yang diberikan pendidik juga tidak sepenuhnya dapat ditangkap peserta didik tingkat sekolah dasar. Bahkan kurangnya peran orangtua dalam membantu dan mendampingi anak dalam mengerjakan tugas dari pendidik berdampak pada psikologis anak sehingga anak malas mengerjakan tugas tersebut.
\end{abstract}

Kata Kunci: Pandemi, Covid 19, Pembelajaran Daring, Psikologis Siswa.

\begin{abstract}
There are restrictions on activities in schools following policies from government due to the covid-19 pandemic, which originally all teaching and learning activities were held face to face, now turned into distance learning by implementing online learning models. The purpose of this study was to obtain an overview and examine the online learning model in the covid-19 period on the psychology of elementary school students. The method used is a qualitative approach in the form of a literature study. Analysis of the data used using content analysis, namely collecting, recording, processing data and drawing conclusions to become scientific data. The results of this research show that the online learning model that has been running for one year is not effective for elementary school students. The results of the delivery of learning provided by educators are also not fully captured by elementary schools students. Even the lack of parental roles in helping and assisting children in carrying out the tasks of educators has an impact on children's psychology so that children are lazy to do these tasks.
\end{abstract}

Keywords: Pandemic, Covid 19, Online Learning, Students Psychology.

Copyright (c) 2021 Fatimah Nur Rahma, Fransisca Wulandari, Difa U1 Husna

$\triangle$ Corresponding author

Email : fatimah1900031012@webmail.uad.ac.id

DOI : https://doi.org/10.31004/edukatif.v3i5.864

ISSN 2656-8063 (Media Cetak)

ISSN 2656-8071 (Media Online)

Edukatif : Jurnal Ilmu Pendidikan Vol 3 No 5 Tahun 2021 p-ISSN 2656-8063 e-ISSN 2656-8071 
2471 Pengaruh Pembelajaran Daring di Masa Pandemi Covid-19 bagi Psikologis Siswa Sekolah Dasar Fatimah Nur Rahma, Fransisca Wulandari, Difa Ul Husna

DOI: https://doi.org/10.31004/edukatif.v3i5.864

\section{PENDAHULUAN}

Dalam undang-undang sistem pendidikan nasional, sekolah dasar merupakan jenjang pendidikan yang paling dasar pada pendidikan formal yang ada di Indonesia. Pendidikan dasar diselenggarakan untuk mengembangkan sikap dan kemampuan serta memberi pengetahuan dan keterampilan dasar yang diperlukan untuk hidup dalam masyarakat serta mempersiapkan peserta didik yang memenuhi persyaratan untuk melanjutkan pendidikan ke tingkat menengah. Subjek utama dari pendidikan adalah siswa atau peserta didik. Dalam mewujudkan praktek pendidikan dan pembelajaran yang baik, pendidik berkewajiban mengetahui dan mendalami karakteristik anak di Sekolah dasar. Salah satu karakteristik anak usia sekolah dasar adalah bermain. Pendidik diharuskan paham dengan perkembangan anak, memberikan aktivitas fisik dengan bermain. Hal ini akan sangat menetukan terhadap program pendidikan dan pembelajaran yang akan dilakukan oleh seorang guru dan juga orangtua selama proses pendidikan berlangsung. Setiap program pendidikan dan pembelajaran di sekolah dasar pada setiap mata pelajaran harus mampu menampilkan kegiatan-kegiatan yang menarik perhatian anak sehingga dengan sukarela dan antusias anak akan mengikuti pembelajaran yang diberikan (Nugraha et al., 2020). Adanya pandemi covid-19 yang terjadi di seluruh dunia termasuk Indonesia, berdampak pada seluruh sektor tanpa terkecuali sektor pendidikan. Dalam upaya tanggap bencana, pemerintah melalui Kementrian Pendidikan dan kebudayaan, mengeluarkan kebijakan belajar mengajar pada seluruh tingkatan pendidikan mulai dari pendidikan tingkat dasar, tingkat menengah bahkan perguruan tinggi yang telah diatur dalam Permendikbud Nomor 3 Tahun 2020 tentang pencegahan covid-19 pada Satuan Pendidikan dan Nomor 36926/MPK.A/HK/2020 tentang Pembelajaran Jarak Jauh dengan memanfaatkan teknologi sebagai media pembelajaran (Sari et al., 2021). Proses belajar mengajar yang semula dilakukan dengan cara tatap muka antara guru dan murid di kelas untuk sementara diganti dengan pembelajaran jarak jauh baik daring (dalam jaringan) dengan menggunakan gadget maupun laptop atau komputer maupun luring (luar jaringan) dengan menggunakan televisi, radio, lembar kerja, dan juga modul belajar mandiri (Sarwa, 2021). Usaha ini diharapkan dapat memutus rantai penyebaran virus yang diakibatkan oleh SARS-CoV-2 pada satuan lembaga pendidikan.

Pembelajaran dalam jaringan (Daring) adalah pembelajaran yang dilaksanakan dengan virtual dengan memanfaatkan media grup online yang tersedia seperti whatsapp, google classroom, dan juga zoom. Dalam pelaksanaannya, pembelajaran daring membutuhkan suatu alat komunikasi seperti gadget, komputer maupun laptop yang terhubung dengan internet yang dapat menghubungkan guru dan murid dalam melakukan pembelajaran. Selain harus tersedianya alat komunikasi yang dibutuhkan, pelaksanaan pembelajaran daring juga harus memerhatikan beberapa aspek pada peserta didik antara lain aspek psikologis, diktatis, dan pedagogis secara bersamaan (Fatimah et al., 2021). Psikologis merupakan bagian dari psikologi, psikologi sendiri merupakan studi yang membahas perilaku dan pikiran seseorang. Psikologis adalah objek dari studi psikologi yang berkaitan dengan pikiran dan fenomena mental pada seseorang. Kondisi psikologis pada seseorang dapat mempengaruhi kehidupan sehari-harinya, diantaranya bisa mempengaruhi pikiran, terutama pada fungsi dari kesadaran, perasaan dan motivasi seseorang (Sendari, 2020). Rata-rata usia anak yang masuk sekolah dasar adalah 6 tahun sampai dengan selesai pada usia 12 tahun. Anak-anak yang memasuki sekolah dasar, memiliki karakteristik yang berbeda dengan anak sekolah menengah. Mereka lebih senang bermain, bergerak, bekerja dalam kelompok dan juga senang melakukan sesuatu secara langsung (Desmita, 2009). Penerapan pembelajaran daring di sekolah dasar, pendidik juga harus mengacu pada karakteristik peserta didik yang masih senang bermain dengan menerapkan metode pembelajaran yang menyenangkan sehingga psikologis peserta didik tidak terbebani dengan tugas-tugas yang diberikan dan peserta didik juga merasa senang menerima materi yang diberikan pendidik.

Pembelajaran daring di sekolah dasar pada masa pandemi saat ini dirasa belum mencapai tujuan pembelajaran. Tujuan adalah dasar untuk mengukur keberhasilan pembelajaran dan juga menjadi landasan 
2472 Pengaruh Pembelajaran Daring di Masa Pandemi Covid-19 bagi Psikologis Siswa Sekolah Dasar Fatimah Nur Rahma, Fransisca Wulandari, Difa Ul Husna

DOI: https://doi.org/10.31004/edukatif.v3i5.864

untuk menentukan materi, strategi, media, serta evaluasi pembelajaran, dengan demikian apa yang dilakukan siswa adalah upaya untuk mencapai tujuan pembelajaran. Namun selama pembelajaran daring berlangsung, mayoritas siswa sekolah dasar tidak memahami materi yang telah diberikan, sehingga perlu dijelaskan kembali oleh orang tuanya maupun saudaranya, terkadang yang belajar bukan siswanya namun orang tuanya. Siswa SD memiliki karakteritik yang unik dan berbeda-beda sehingga membutuhkan perhatian khusus dari pendidik dan orang tua. Setiap siswa memiliki motivasi, kemampuan, tingkat pengetahuan, latar belakang serta sosial ekonomi yang berbeda, penilaian karakteristik siswa kurang efektif selain itu siswa juga kurang aktif dalam mengikuti pembelajaran daring.

Pada penelitian sebelumnya juga telah menghasilkan data mengenai analisis Pengaruh Pembelajaran Daring terhadap Psikologis Siswa yang.dilakukan oleh Safira Rona Mahmudah (Mahmudah, 2020), namun pada penelitiannya belum menfokuskan subjek yang akan dituju, sedangkan dalam jurnal ini, kami fokuskan pada siswa sekolah dasar. Pentingnya penelitian ini dibuat untuk memperoleh gambaran dan menelaah model pembelajaran daring terhadap psikologis siswa sekolah dasar agar dapat dijadikan evaluasi bagi pendidik dan orang tua.

\section{METODE PENELITIAN}

Penelitian ini menggunakan metode pendekatan kualitatif dalam bentuk studi kepustakaan. (Cresweel, 2015). Studi kepustakaan merupakan kegiatan pengumpulan data, membaca, menulis, dan mengolah data objek penelitian menjadi suatu data yang valid (Mestika, 2008). Peneliti dapat memanfaatkan perpustakaan sebagai sumber informasi/data dalam pengolahan karya ilmiahnya. Sumber data penelitian adalah literature dari buku, jurnal, dan sumber lainnya mengenai psikologi perkembangan anak sekolah dasar, covid-19, dan pembelajaran daring.

Tahapan dalam penelitian ini yaitu penulis mengumpulkan riset kepustakaan seperti jurnal ilmiah, buku, e-paper, serta sumber lainnya. Kemudian penulis menggunakan teknik dokumentasi yaitu mencari dan menjadikan satu bahan yang relevan dari buku, jurnal, berita, maupun sumber yang reliabel baik secara manual maupun digital. Pada penelitian ini penulis menggunakan 13 jurnal penelitian yang terbit pada tahun 2020 dan 2021, 3 buku, serta yang berkaitan dengan psikologis siswa SD di masa pandemi. Peneliti membaca, menulis catatan penelitian dan menyimpulkan seluruh bahan informasi yang diperoleh hingga menjadi sebuah jurnal. Analisis data dilakukan dengan menggunakan analisis isi. Mengolah bahan informasi yang telah dikumpulkan baik berupa jurnal penelitian, buku dan dokumen pendukung lainnya menjadi sebuah artikel ilmiah.

Peneliti menggunakakan teknik studi dokumentasi untuk memperoleh data yang dibutuhkan. Alasan peneliti mengukan teknik studi dokumentasi sebagai penelitian yaitu 1) studi dokumentasi merupakan sumber yang stabil, kaya akan pengetahuan, dan mendorong untuk pembacanya, 2) memiliki sifat alamiah, dan sesuai dengan konteks, 3) relatif murah dan tidak sulit ditemukan, hanya membutuhkan waktu, 5) hasil dari pengkajian isi dapat membuka kesempatan bagi pembacanya memperluas pengetahuan yang sedang diselidiki(Anggito \& Setiawan, 2018).

\section{HASIL DAN PEMBAHASAN PENELITIAN}

\section{Pembelajaran Daring Di Masa Pandemi}

Pembelajaran merupakan suatu proses yang digabungkan dari dua aspek yaitu, belajar yang mengarahkan siswa pada apa yang harus mereka lakukan, belajar mengarah pada apa yang diajarkan oleh pendidik sebagai pemberi pembelajaran merupakan suatu aktivitas belajar mengajar yang didalamnya terdapat 
2473 Pengaruh Pembelajaran Daring di Masa Pandemi Covid-19 bagi Psikologis Siswa Sekolah Dasar Fatimah Nur Rahma, Fransisca Wulandari, Difa Ul Husna

DOI: https://doi.org/10.31004/edukatif.v3i5.864

kolerasi positif antara pendidik dan siswa dengan mengerahkan semua potensi dan sumber yang ada untuk menghasilkan kondisi yang aktif serta menyenangkan (Gilang K, 2020).

Sejak WHO menetapkan Covid-19 sebagai pandemi, pemerintah Indonesia membuat kebijakankebijakan untuk mencegah penyebaran covid-19, salah satunya yaitu pembelajaran tatap muka dialihkan menjadai pembelajaran dalam jaringan (daring). Pembelajaran daring adalah pembelajaran yang dilakukan secara online dengan menggunakan aplikasi pembelajaran maupun jejaring sosial. Belajar daring adalah metode belajar yang menggunakan model interaktif berbasis internet dan Learning Managemen System (LMS) seperti zoom, google meet, dll. Pembelajaran daring menggunakan platform untuk memudahkan proses belajar mengajar meskipun dilakukan dengan jarak jauh (Handarini \& Wulandari, 2020). Pada tingkat sekolah dasar, platform biasanya pendidik menggunakan aplikasi google classroom, zoom, whatsapp gorup dan media online lainnya dalam menyampaikan materi dan memberi tugas untuk memaksimalkan kegiatan belajar mengajar. Selain faktor pendukung smartphone dan kuota internet, pembelajaran daring juga memiliki faktor yang menghambat proses pembelajaran tersebut. Adanya rasa malas saat mengerjakan tugas walaupun sudah memiliki handphone dan banyaknya orangtua peserta didik yang bekerja sehingga tidak dapat mendampingi anaknya dalam belajar daring.

Whatsapp adalah aplikasi pengiriman pesan teks atau video dengan menggunakan kuota internet. Aplikasi whatsapp ini dirasa oleh semua kalangan terutama para pendidik, peserta didik, dan orangtua peserta didik sekolah dasar merupakan aplikasi yang mudah digunakan dalam pembelajaran daring. Google classroom merupakan aplikasi yang berbentuk ruang kelas yang terhubung dengan internet. Aplikasi google classroom memiliki fitur assigmenments (pembagian tugas) hingga fitur pengelolaan arsip tugas yang dapat diakses keduanya sehingga terjadinya komunikasi antara guru dan siswa yang dapat mendukung kegiatan pembelajaran daring (Simanihuruk. Lidia, 2019). Kelebihan dari aplikasi google classroom adalah dapat menyederhanakan kegiatan belajar mengajar tanpa menggunakan kertas (Imaduddin, 2018). Para pendidik jarang menggunakan google classroom bahkan hampir tidak pernah karena perlu adanya pembuatan email. Untuk tingkat satu sampai tiga mungkin masih banyak yang belum mengetahui cara membuat email dan belum paham cara pengoperasian google classroom.

Zoom merupakan aplikasi digital untuk berkomunikasi dengan menggunakan video. Aplikasi tersebut dapat digunakan pada berbagai unit selular dan desktop. Aplikasi zoom pertama kali di buat oleh Erik Yuan(Lusiana. Etik, et all, 2021). Aplikasi layanan ini mampu menampung pertemuan virtual sekitar 100 sampai 300 peserta, selain itu aplikasi zoom dapat merekam sesi pertemuan virtual supaya bisa dilihat kembali (Paksi, 2020) Dalam pembelajaran, aplikasi zoom mempermudah pendidik dan peserta didik dalam berinteraksi. Pendidik dapat menshare materi lewat layar smartphone maupun desktop sehingga terlihat peserta didik. Walaupun mudah dalam mengaksesnya, zoom memiliki kekurangan yang membuat kita mengeluarkan cukup banyak kuota internet. Dari ketiga model pembelajaran daring atau pembelajaran jarak jauh tersebut, pendidik tingkat sekolah dasar lebih sering menggunakan aplikasi whatsapp dalam memberikan materi maupun tugas. Para peserta didikpun bisa dengan mudah mengaksesnya tanpa harus menunggu orangtua mereka.

Pendidik berusaha memberikan yang terbaik kepada peserta didik dengan melakukan berbagai inovasi pembelajaran dengan mehadirkan suasana pembelajaran yang interaktif dan menyenangkan agar psikologis peserta didik sekolah dasar tidak terganggu dan bersemangat dalam belajar. Namun dalam penelitian yang dilakukan Hilna Putri dkk, mengugkapkan bahwa pendidik memiliki berbagai kendala dalam pembelajaran daring. Presensi siswa yang mengikuti pembelajaran online tidak dapat mencapai 100 persen. Beberapa siswa yang tidak mengikuti pembelajaran sehingga membingungkan guru dalam memberikan nilai. Proses penilaian saat pembelajaran daring mempunyai skema yang sama dengan pembelajaran tatap muka yaitu ketika peserta didik mampu menyelesaikan tugas dan mengumpulkannya. Pembelajaran daring yang dilaksanakan tingkat sekolah dasar dirasa kurang efektif dengan presentase 70 persen (Hildayani et al., 2014). 
2474 Pengaruh Pembelajaran Daring di Masa Pandemi Covid-19 bagi Psikologis Siswa Sekolah Dasar Fatimah Nur Rahma, Fransisca Wulandari, Difa Ul Husna

DOI: https://doi.org/10.31004/edukatif.v3i5.864

\section{Psikologis Siswa Sekolah Dasar Selama Pembelajaran Daring}

Tahun 2020 nampaknya menjadi tahun yang sulit bagi setiap orang dalam mengahadapi wabah corona. Apalagi pada sektor pendidikan yang mengharuskan lembaga pendidikan melakukan kegiatan belajar dari rumah guna menghentikan lajunya penyebaran virus corona yang semakin parah. Jumlah anak-anak yang terinfeksi Covid-19 memang tidak sebanyak kasus orang dewasa. Namun, bukan berarti anak menjadi terlindungi dari virus tersebut. Menurut Ezra Golberstein peneliti dari Universitas Minnesota mengemukakan bahwa anak-anak bisa mengalami dampak ganda akibat keadaan ini. Saat biasanya siswa melakukan kegiatan belajar dan bermain dengan teman disekolah, berpergian kemana saja dengan mudah kemudian banyaknya perubahan yang terjadi secara tiba-tiba bahkan pembatasan aktivitas di luar rumah merupakan hal yang sulit bagi setiap siswa terutama siswa sekolah dasar. Hal itu menyebabkan siswa dengan mudah mengalami gangguan psikologis dan depresi. Adanya kebijakan belajar dari rumah, orangtua diharapkan mendampingi dan membantu anak dalam belajar dan juga mampu memahami dampak psikologis yang akan dialami anak sehingga peran orangtua sangat dibutuhkan sehingga dapat meminimalisir dampak pandemi covid-19 (Fadilah. Nur, n.d.).

Dari data survei yang dilakukan oleh Satgas Covid-19 menyatakan bahwa 47\% anak mengalami kebosanan di rumah, 35\% anak merasa khawatir akan ketertinggalan dalam pelajaran, 20\% anak merindukan teman-teman sekolahnya, $15 \%$ anak merasa tidak aman, dan $10 \%$ anak merasa khwatir terhadap perekonomian yang menimpa keluarganya (Riany, 2020). Apalagi usia anak yang masuk sekolah dasar memiliki karakter yang senang bermain. Berbeda dengan karakteristik anak usia sekolah menengah, karakteristik anak usia Sekolah Dasar lebih senang bermain, bergerak, senang bekerja kelompok dan juga senang melakukan sesuatu secara langsung. Oleh karena itu, hendaknya pendidik dapat membuat motode pembelajaran yang mengandung unsur permainan.

Orangtua merupakan madrasah pertama dirumah bagi anaknya. Oleh sebab itu, tugas orangtua dalam membimbing dan mengasuh anak sangat berpengaruh dalam proses perkembangan anak. Orangtua memiliki andil dalam mendampingi anak-anak selama pembelajaran daring. Namun setiap orangtua memiliki pola yang bervariasi dengan latar belakang pendidikan orangtua, pekerjaan, keadaan sosial, adat istiadat dan suku bangsa dalam mendampingi anak-anaknya dalam belajar. Beberapa jenis pola asuh orangtua dalam mendampingi anak belajar yaitu pola asuh otoriter, liberal, dan demokratis (Kurnianto \& Rahmawati, 2020).

Pola asuh otoriter merupakan cara mendidik orangtua dengan cara memaksakan kehendak kepada anakanak untuk mengikuti aturan yang dibuat oleh orangtua (Hidayati, 2014). Pola asuh liberal adalah cara mendidik dengan memberi kebebasan kepada anak sesuai dengan keinginan anak sehingga anak menjadi manja, agresif, dan implusif (Nurrachma. Evy, n.d.). Sedangkan pola asuh demokratif merupakan cara orangtua dalam mendidik anaknya dengan friendly, responsif dan mengajak anak untuk mengontrol diri.Selain itu, anak yang diasuh dengan pola demokratif dapat menjadi anak yang bertanggungjawab serta mampu mengatur diri sendiri (Kurnianto \& Rahmawati, 2020). Dari ketiga cara mendidik dan merawat anak yang telah dijelaskan diatas, pola asuh demokratif sangat relevan untuk diterapkan oleh orangtua dalam mendampingi anak dalam belajar di era pandemi. Dengan pola asuh demokratif, orang tua tidak serta merta menuruti semua keinginan anaknya. Penerapan pola asuh dari orangtua yang baik dapat mempengaruhi motivasi belajar siswa baik di sekolah maupun di rumah. Selama pandemi masih berlangsung, proses belajar mengajar dilakukan dengan sistem pembelajaran yang fleksibel yaitu pembelajaran online. Proses belajar bisa diakses dengan mudah melalui media online dengan menggunakan aplikasi whatsapp, google classroom, dan zoom. Dengan adanya pembelajaran online aktivitas siswa mengunakan smartphone menjadi lebih sering.

Penggunaan smartphone yang berlebihan mempunyai dampak positif dan negatif pada pemakainya. Jika dilihat pada sisi positif saat pembelajaran online, smartphone merupakan salah satu alat utama untuk melakukan pembelajaran yang menghubungkan aktivitas antara guru dan siswa. Namun jika dipandang dari penggunaannya yang terlalu sering oleh peserta didik membuatnya menjadi ketergantungan pada smartphone. 
2475 Pengaruh Pembelajaran Daring di Masa Pandemi Covid-19 bagi Psikologis Siswa Sekolah Dasar Fatimah Nur Rahma, Fransisca Wulandari, Difa Ul Husna

DOI: https://doi.org/10.31004/edukatif.v3i5.864

Jika dalam penggunaan smartphone tidak didampingi orangtua, maka anak bisa berlebihan bahkan ketergantungan sehingga menyebabkan psikologis anak menjadi terganggu (Shin, 2013).

Setiap anak memiliki karakteristik yang berbeda-beda dalam melakukan pembelajaran daring. Dilihat dari aspek kognitif, siswa SD berada pada pra operasional konkret sehingga dalam belajar, mereka akan lebih mudah menerima informasi yang kontekstual (Urbayatun. Siti, 2019). Hal-hal yang dapat mempengaruhi psikologi siswa antara lain siswa sulit memahami materi yang diberikan, jumlah tugas yang diberikan oleh guru terlalu banyak, selama pembelajaran daring merasa sendiri ketika belajar, kosentrasi belajar menurun, dan masih banyak faktor yang dapat mempengaruhi psikologis siswa. Hasil observasi yang dilakukan Yadi Jatira dan S Neviyarni mengenai kondisi siswa SD ketika belajar daring menjadikan siswa mudah marah dan jadi malas. Hal ini disebabkan ketika anak-anak sedang asyik bermain, anak disuruh orangtua untuk mengejar tugas dari guru, atau ketika anak sedang mengerjakan tugas orangtua malah menyuruh anak untuk memabantu pekerjaan rumah. Situasi yang seperti ini membuat pola berfikir anak menjadi terganggu hingga menyebabkan anak jadi sering menangis (Jatira \& Neviyarni, 2021).

Kondisi yang terjadi diperkuat dengan observasi yang dilakukan oleh Andi Suhandi dan Issaura Sherly Pamela, jika belajar daring membuat mental siswa terganggu sehingga siswa menjadi mudah emosi, sedih, jenuh, dan kadang marah (Suhandi \& Pamela, 2020). Faktor lain yang dapat mempengaruhi pesikologis anak yaitu trauma anak, dimana ada kenangan yang sangat berkesan atau mengecewakan, anak merasa sendiri ketika belajar daring berbeda ketika siswa melakuan pembelajaran tatap muka di sekolah (Rosdiana \& Hastutiningtyas, 2021). Sedangkan menurut Fadillah Nur, anak-anak yang melakukan pembelajaran daring dengan berdiam diri dirumah akan mengalami krisis mental dan emosi yang tidak stabil menyebabkan prestasi menurun. Adapun gejalanya ialah perubahan suasan hati, perasaan yang kuat, perubahan perilaku dan sulit untuk berkonsentrasi. Emosi merupakan perasaan yang ditujukan kepada seseorang. Mudah bosan dan mudah tertekan berpotensi stress pada anak merupakan salah satu dampak dari pembelajaran daring (Fadilah. Nur, n.d.).

Peran keluarga terutama orangtua sangat dibutuhkan selama pembelajaran daring (dalam jaringan) dalam membimbing dan mendampingi anak ketika belajar. Mendampingi anak-anak dalam menggunakan smartphone tidak hanya duduk menemani saja, namun juga memberi arahan kepada anak untuk bijak dalam menggunakan aplikasi yang ada di smartphone. Dalam mendampingi anak perlu dilakukan secara bijaksana namun tetap menghargai privasi anak (Khalimah, 2021). Selama pembelajaran daring berlangsung, komunikasi antara orangtua dan guru sangat dibutuhkan.Orangtua juga harus memastikan tugas yang diberikan guru kepada anak-anaknya sudah dikerjakan atau belum(Rahmania et al., 2021).Dalam mendampingi anak-anak, hendaknya orangtua memberikan perhatian dan motivasi kepada anak-anak. Perhatian dan motivasi orangtua dapat meningkatkan mood belajar anak-anak. Ketika anak-anak bersemangat dalam belajar, maka hal ini dapat mengembangkan psikologi anak (Sun'iyah, 2020). Selain itu, pendidik juga perlu memberikan motivasi kepada siswa agar tumbuh rasa semangat belajar ada diri siswa. Contohnya guru memberikan tugas kepada siswa dengan instruksi yang menarik, menyenangkan juga menantang. Gurudiharuskan mampu menguasai dan berkreasi dengan teknologi di era digital ini agar pembelajaran daring tidak menjadi monoton dan mampu meningkatkan semangat belajar siswa hingga pandemi berakhir (Putria et al., 2020).

\section{KESIMPULAN}

Berdasarkan hasil dari penelitian dan pembahasan tampak adanya pengaruh psikologis yang terjadi pada siswa sekolah dasar jika terlalu lama mengikuti pembelajaran daring. Belajar dari rumah yang diterapkan pemerintah mempunyai dua jenis antara lain pembelajaran daring atau online dan pembelajaran luring atau offline. Pembelajaran model online adalah cara yang dirasa aman saat terjadinya pandemi corona virus. 
2476 Pengaruh Pembelajaran Daring di Masa Pandemi Covid-19 bagi Psikologis Siswa Sekolah Dasar Fatimah Nur Rahma, Fransisca Wulandari, Difa Ul Husna

DOI: https://doi.org/10.31004/edukatif.v3i5.864

Walaupun pembelajaran daring dirasa kurang efektif jika diterapkan pada tingkat sekolah dasar, akan tetapi kebijakan ini diperlukan guna memutus rantai penyebaran covid-19. Meskipun jumlah kasus terhadap anakanak tidak sebanyak kasus pada orang dewasa, akan tetapi kesehatan dan keselamatan anak-anak perlu dijaga. Pembelajaran daring yang terlalu lama dapat mempengaruhi psikologis siswa Sekolah Dasar. Pengunaan smartphone yang berlebihan tanpa pegawasan orangtua membuat siswa tidak dapat mengontrol diri, krisis mental dan mudah emosi. Pendidik juga diharapkan mampu membuat pembelajaran daring yang menyenangkan dikarenakan karakteristik usia anak pada sekolah dasar adalah bermain. Peran orangtua saat dirumah dan komunikasi antara orangtua dan guru sangat dibutuhkan selama pembelajaran daring tetap dilaksanakan. Pola asuh yang relevan untuk mendampingi anak belajar akan membuat anak lebih diperhatikan dan dapat memotivasi anak dalam belajar.

\section{UCAPAN TERIMA KASIH}

Kami ucapkan terimakasih kepada seluruh pihak yang terlibat dalam pembuatan jurnal ini.

\section{DAFTAR PUSTAKA}

Anggito, A., \& Setiawan, J. (2018). Metodologi Penelitian Kualitatif. CV Jejak (Jejak Publisher).

Cresweel, J. W. (2015). Penelitian Kualitatif Dan Desain Riset. International Jurnal Of Physology (Vol. 3).

Desmita, D. (2009). Psikologi Perkembangan Peserta Didik. Remaja Rosdakarya.

Fadilah. Nur. (N.D.). Pusaran Covid-19. Catatan Para Analisis Muda (Usman (Ed.)). IAIN Parepare Nusantara Press.

Fatimah, D., Chan, F., \& Sofwan, M. (2021). Analisis Pelaksanaan Pembelajaran Daring Pada Masa Pandemi Covid-19 Di Sekolah Dasar. Universitas Jambi.

Gilang K, R. (2020). Pelaksanaan Pembelajaran Daring Di Era Covid-19 (L. Nurtika (Ed.); Pertama). Penerbit Lutfi Gilang.

Handarini, O. I., \& Wulandari, S. S. (2020). Pembelajaran Daring Sebagai Upaya Study From Home (SFH) Selama Pandemi Covid 19. Jurnal Pendidikan Administrasi Perkantoran (JPAP), 8(3), 496-503.

Hidayati, N. I. (2014). Pola Asuh Otoriter Orang Tua, Kecerdasan Emosi, Dan Kemandirian Anak SD. Persona: Jurnal Psikologi Indonesia, 3(01).

Hildayani, R., Sugianto, M., Tarigan, R., \& Handayani, E. (2014). Psikologi Perkembangan Anak.

Imaduddin, M. (2018). Membuat Kelas Online Berbasis Android Dengan Google Classroom: Terobosan Pembelajaran Era Revolusi Industri 4.0. Garudhawaca.

Jatira, Y., \& Neviyarni, S. (2021). Fenomena Stress Dan Pembiasaan Belajar Daring Dimasa Pandemi Covid19. Edukatif: Jurnal Ilmu Pendidikan, 3(1), 35-43.

Khalimah, N. (2021). Peran Orang Tua Dalam Pembelajaran Daring Di Mi Darul Ulum Pedurungan Kota Semarang Tahun Pelajaran 2020/2021 Skripsi.

Kurnianto, B., \& Rahmawati, R. D. (2020). Hubungan Pola Asuh Orang Tua Terhadap Motivasi Belajar Siswa Pada Pembelajaran Daring Masa Pandemi. Seminar Pendidikan Nasional (SENDIKA), 2(1).

Lusiana. Etik, Et All, E. (2021). Oase Pandemi Covid-19 Based On True Stories (A. T. Khatir. Rita (Ed.)). Syiah Kuala University Press.

Mahmudah, S. R. (2020). Pengaruh Pembelajaran Daring Terhadap Psikologis Siswa Terdampak Social Distancing Akibat Covid 19. Al-Mau'izhoh, 2(2). 
2477 Pengaruh Pembelajaran Daring di Masa Pandemi Covid-19 bagi Psikologis Siswa Sekolah Dasar Fatimah Nur Rahma, Fransisca Wulandari, Difa Ul Husna

DOI: https://doi.org/10.31004/edukatif.v3i5.864

Mestika, Z. (2008). Metode Penelitian Kepustakaan. Yayasan Obor Indonesia.

Nugraha, M. F., Hendrawan, B., Pratiwi, A. S., Permana, R., Saleh, Y. T., Nurfitri, M., Nurkamilah, M., Trilesatri, A., \& Husen, W. R. (2020). Pengantar Pendidikan Dan Pembelajaran Di Sekolah Dasar. EDU PUBLISHER.

Nurrachma. Evy, Dkk. (N.D.). Pengaruh Pasangan Penikahan Dini Terhadap Pola Pengasuhan Anak Di Kelurahan Mangkurawang Kecamatan Tenggarong Kabupaten Kutai Kartanegara Tahun2018.

Paksi, H. P. (2020). Sekolah Dalam Jaringan. Scopindo Media Pustaka.

Putria, H., Maula, L. H., \& Uswatun, D. A. (2020). Analisis Proses Pembelajaran Dalam Jaringan (Daring) Masa Pandemi Covid-19 Pada Guru Sekolah Dasar. Jurnal Basicedu, 4(4), 861-870.

Rahmania, S., Wijayanti, R., \& Hakim, S. L. (2021). Strategi Orang Tua Dalam Pendampingan Belajar Anak Selama Pandemi Covid-19. Literasi: Jurnal Kajian Keislaman Multi-Perspektif, 1(1), 99-110. Https://Doi.Org/10.22515/Literasi.V1i1.3259

Riany, Y. E. (2020). Mengelola Kesehatan Mental Siswa Di Masa Pandemi. Media Indonesia. Https://Mediaindonesia.Com/Opini/359889/Mengelola-Kesehatan-Mental-Siswa-Di-Masa-Pandemi

Rosdiana, Y., \& Hastutiningtyas, W. R. (2021). Reaksi Psikologis Anak Belajar Daring (Online) Pada Masa Pandemi Covid-19 Di Sdn Sumberejo 1 Purwosari Pasuruan. Nursing News: Jurnal Ilmiah Keperawatan, 5(1), 16-23.

Sari, R. P., Tusyantari, N. B., \& Suswandari, M. (2021). Dampak Pembelajaran Daring Bagi Siswa Sekolah Dasar Selama Covid-19. Prima Magistra: Jurnal Ilmiah Kependidikan, 2(1), 9-15.

Sarwa, S. S. (2021). Pembelajaran Jarak Jauh: Konsep, Masalah Dan Solusi. Penerbit Adab.

Sendari, A. A. (2020). Psikologis Adalah Bagian Dari Psikologi, Kenali Macam Gangguannya. Liputan6. Https://Hot.Liputan6.Com/Read/4443734/Psikologis-Adalah-Bagian-Dari-Psikologi-Kenali-MacamGangguannya

Shin, Y. J. (2013). Mendidik Anak Di Era Digital. Mizan Digital Publishing.

Simanihuruk. Lidia, Et All. (2019). E-Learning Implementasi, Strategi, Dan Inovasinya (L. Tonni (Ed.)). Yayasan Kita Menulis.

Suhandi, A., \& Pamela, I. S. (2020). Dampak Musim Libur Covid-19 Belajar Dari Rumah Terhadap Psikologi Anak Sekolah Dasar Andi Suhandi 1 , Issaura Sherly Pamela 2 12). 5(2), 207-218.

Sun'iyah, S. L. (2020). Sinergi Peran Guru Dan Orang Tua Dalam Mewujudkan Keberhasilan Pembelajaran Pai Tingkat Pendidikan Dasar Di Era Pandemi Covid-19. DAR EL-ILMI: Jurnal Studi Keagamaan, Pendidikan Dan Humaniora, 7(2), 1-16.

Urbayatun. Siti, D. (2019). Kesulitan Belajar Dan Gangguan Psikologis Ringan Pada Anak (Implementasi Pada Anak Usia Sekolah Dasar). K-Media. 